\title{
Od osobowości autorytarnej do uzasadniania systemu. Elementy teorii krytycznej w psychologicznych koncepcjach wyjaśniających wrogość międzygrupową
}

\section{From Authoritarian Personality to System Justification: Elements of Critical Theory in Psychological Conceptions of Intergroup Hostility}

\begin{abstract}
The article presents selected aspects of critical theory applied in intergroup hostility research in the mainstream of political psychology. Aims, fields of research and distinct methodology of critical psychology are discussed as a starting point. In the main part of the paper, the author considers the problem of authoritarian personality and the idea of stereotypes as false consciousness in the system justification theory, as well as its influence on the mainstream political psychology research. The article ends with a short reflection on the usefulness of critical approach in contemporary political psychology.
\end{abstract}

Keywords: critical theory, authoritarian personality, system justification theory, political theory, political psychology

\section{Wprowadzenie}

Biorąc pod uwagę dominujące współcześnie metodologiczne standardy w badaniach w obszarze psychologii polityki, jak i wynikające stąd wnioskowania odnoszące się do wskazywania związków i relacji między poszczególnymi zjawiskami, wydawać się może, że teoria krytyczna w psychologii polityki odgrywa głównie role historyczne. I nawet jeśli także dziś niektórzy autorzy kontynuują tę tradycję myślenia, to owe refleksje nie należą do mainstreamu psychopolitycznych badań. W ostatnich dekadach rozmaite metody ilościowe (zarówno procedury eksperymentalne, jak i badania z wykorzystaniem technik 
standaryzowanych kwestionariuszy) skutecznie wyparły i zastąpiły studia jakościowe w badaniu psychologicznych podstaw zjawisk politycznych (Monroe i in., 2009, s. 866) ${ }^{1}$. Nie oznacza to jednak zupełnego braku refleksji krytycznej w psychologii. Przeciwnie, ma się ona całkiem nieźle, głównie za sprawą rozwijającej się dynamicznie w ostatnich dwudziestu latach psychologii krytycznej (Parker, 1999, s. 3). Wykracza ona wszakże poza pole psychologii polityki i obejmuje wiele koncepcji, których elementem wspólnym, jak powiada Thomas Teo, jest odwołanie się do myślenia krytycznego rozwijanego od czasów starożytnych, choć właściwym punktem odniesienia jest Karol Marks i szkoła frankfurcka. Role wielkich mistrzów odgrywają w niej także Zygmunt Freud, Jacques Lacan czy Michel Foucault, by wspomnieć tylko niektórych (Teo, 2012, s. 236-242).

Celem psychologii krytycznej jest zrozumienie psychologicznych uwarunkowań procesów ekonomicznych, społecznych, historycznych i politycznych w celu poszukiwania sprawiedliwości społecznej, oporu wobec status quo, emancypacji. Ma być więc ona zbiorem teorii radykalnych i wyzwalających, zmieniających świat społeczny na lepszy, uwalniających od dominacji i podporządkowania, krzywdy i niegodziwości, nierówności i wyzysku (Teo, 2012, s. 236-237). Psycholodzy krytyczni odnoszą się sceptycznie do dominującego w dyscyplinie mechanistycznego modelu psychiki człowieka koncentrującego się na nielicznych i izolowanych zmiennych, a co za tym idzie, odseparowanego od społecznych, ekonomicznych i politycznych uwarunkowań. Innymi słowy, właściwa - krytyczna - refleksja psychologiczna powinna ujmować człowieka w kategoriach splątania jednostki i społeczeństwa, gdzie dialogiczne „ja” powstaje nie tylko w relacji z ,innym”, ale także zanurzone jest w historii i czasie ${ }^{2}$. Inna jest także perspektywa metodologiczna psychologii krytycznej. O ile bowiem dominujące w psychologii podejścia są zorientowane naturalistycznie, $\mathrm{z}$ naciskiem na metody ilościowe, o tyle refleksja krytyczna opiera się na metodach i technikach głównie (choć niekoniecznie) jakościowych (Teo, 2012, s. 241-243). Teo uważa nawet, że na najogólniejszym poziomie metodologia badań krytycznych powinna szeroko wspierać się na ideach dekonstrukcji, konstrukcji i rekonstrukcji, a przez to odsłaniać ukryte mechanizmy społeczno-politycznej opresji (1999, s. 124-127). Psychologia krytyczna powinna także uciec od błędnej separacji faktów i wartości i uznać swój emancypacyjny po-

Warto jeszcze dodać, że w badaniach Monroe i współpracowników brano pod uwagę: typy artykułów ukazujących się w periodyku Political Psychology, laureatów nagród im. Roberta Lane’a i Alexandra George'a przyznawanych odpowiednio przez sekcję psychologii polityki APSA i ISPP, badania prezydentów ISPP zarysowane w ich presidential address, opublikowane w Political Psychology, oraz analizy wybranych programów studiów psychologicznych.

2 Model osobowości akceptowany przez psychologów krytycznych został bodaj najpełniej przedstawiony przez Kennetha J. Gergena (1973, s. 309-320; Gergen 2009). 
tencjał: powinna być nauką praktyczną podsuwającą rozwiązania problemów społeczno-politycznych i prowadzącą do świata w jakimś stopniu lepszego (Teo, 2012, s. 243-244)33; powinna również umożliwiać sojusz między badaczami, politykami i obywatelami w celu zmiany społecznej - powinna przezwyciężać alienację i wzmacniać humanizm (Parker, 2015, s. 3-7).

Pole badawcze psychologii krytycznej jest równie szerokie jak samej psychologii, nie idzie tu bowiem tylko o nową subdyscyplinę, ale też o inne spojrzenie na problemy poruszane przez psychologów, a nawet o ich rozszerzenie na obszary pomijane, na których badacze mogliby spotkać się z historykami, ekonomistami, socjologami czy politologiami. Co za tym idzie, psycholodzy krytyczni zajmują się zarówno klasycznymi problemami psychologii (np. emocjami, osobowością), jak i kwestiami społecznymi i politycznymi, w szczególności rasizmem, klasami społecznymi, gender, feminizmem, postkolonializmem, traumą społeczną, mechanizmami opresji społecznej i innymi jeszcze (Fox, Prilleltensky, Austin, 2009) ${ }^{4}$. Psychologia krytyczna ma więc zamysł integrujący rozliczne podejścia, a nawet powinna prowadzić do likwidacji subdyscyplin, jako takich, które ograniczają możliwości całościowego zrozumienia procesów psychospołecznych (Parker, 2015, s. 2). Przyjmując wiele form i pojawiając się w wielu ujęciach teoretycznych, jest raczej orientacją badawczą, która ma nie tylko pokazać rolę mechanizmów psychologicznych w procesach społeczno-politycznych, ale także zedrzeć z mainstreamowej psychologii maski obiektywizmu i neutralności, odsłaniając jej ideologiczne i polityczne uwikłanie w tworzenie oraz podtrzymywanie dominacji krajów wysoko rozwiniętych i wartości kapitalistycznej demokracji (Hook, 2004, s. 11-14). Jasno przedstawia to Ian Parker:

Nie odkrywamy psychologii, ale żyjemy nią i ją produkujemy. To, co my - krytyczni psychologowie, chcemy wlączyć do psychologii, to różne sposoby, w jakie mężczyźni i kobiety różnych kultur i klas konstruują i w jaki sposób myślą nad działaniem i doświadczeniem. Wszystkie te sposoby w przeszłości i teraźniejszości powinny znajdować się w naszym zasięgu . Krytyczna psychologia jest zatem przede wszystkim systematycznym badaniem tego, jak niektóre odmiany psychologicznego działania i doświadczenia są uprzywilejowane w stosunku do innych, jak dominujące podejścia „psychologii” operują ideologicznie i w służbie władzy (Parker, 1999, s. 13).

Inni badacze dodają, że wiele dominujących nurtów badań psychologicznych popełnia błędy w postaci separacji obiektu badania od jego otoczenia przez wyrwanie refleksji nad psychiką ludzką z kontekstu społecznego oraz zaprzeczenie self $\mathrm{i}$ society na rzecz nadrzędności tego pierwszego (Hook, 2004, s. 15).

4 Doskonały przegląd rozmaitych problemów badawczych psychologii krytycznej zawierają poszczególne numery Annual Review of Critical Psychology, dostępne na stronie internetowej: https://discourseunit.com/annual-review/ (dostęp: 30.12.2017). 
Ten nieco przydługi wstęp przypominający o pozostającym, co prawda na obrzeżach „oficjalnej nauki”, lecz ważnym i bogatym nurcie psychologii krytycznej, ma na celu wyraźne podkreślenie, że refleksja krytyczna w tej dyscyplinie nie tylko nie została zaniechana, ale rozwija się, zwłaszcza w ostatnich dziesięcioleciach. Nie pozostaje to $\mathrm{w}$ sprzeczności z przekonaniem wyrażonym na samym początku, że tak czy owak kwestie te nie były i nie są żelaznymi tematami psychologii polityki, szczególnie głównego nurtu (Augoustinos, 1999, s. 310). Można więc powiedzieć, że mamy do czynienia z dwiema różnymi orientacjami, które współistniejąc obok siebie, niewiele z siebie czerpią. A jednak w owej mainstreamowej psychologii polityki doszło w ostatnich latach do intrygującego i ciekawego powrotu elementów teorii krytycznej i to pomimo przekonania o jej historycznym, przede wszystkim, charakterze ${ }^{5}$. Mam tu na myśli sformułowaną przez Johna T. Josta i Mahazarin Banaji teorię uzasadniania systemu, w której autorzy skorzystali z idei fałszywej świadomości.

Ten artykuł ma na celu przedstawienie miejsca i roli teorii krytycznej w badaniach psychologii polityki, z pominięciem wszakże psychologii krytycznej, oraz stanowi próbę odpowiedzi na pytanie, czy współczesna psychologia polityki głównego nurtu może skorzystać na włączeniu kategorii z zakresu teorii krytycznej do swoich badań. Spróbuję tu pokazać, że bogata, acz krótka, historia refleksji krytycznej w psychologii polityki nie skończyła się wcale wraz ze wskazaniem słabości koncepcji osobowości autorytarnej wypracowanej przez badaczy skupionych wokół Theodora W. Adorna. Choć co prawda teoria krytyczna nigdy więcej nie była już ujęciem dominującym i organizującym cały obszar badań mainstreamowej psychologii polityki, to jednak jej elementy były i są wykorzystywane do zrozumienia postaw politycznych i ich uwarunkowań. By pokazać meandry i zawiłości pojawiania się, znikania i powrotu idei związanych z teorią krytyczną w badaniach psychologii polityki, najpierw przybliżę jej pierwszą i najważniejszą odsłonę, to jest koncepcję osobowości autorytarnej i jej krytykę, by następnie skupić się na idei fałszywej świadomości w teorii uzasadniania systemu.

Trzeba jeszcze podkreślić, że punktem spajającym owe rozważania jest zagadnienie wrogości międzygrupowej i jej czynników. Wrogość międzygrupową traktuję tu wąsko ${ }^{6}$, jako postawę opartą na stereotypach (aspekt poznawczy), uprze-

Warto przypomnieć, że obok pionierskich badań Harolda Lasswella przedstawionych w słynnej pracy Psychopathology and Politics głównym ośrodkiem inicjującym myślenie o psychologicznych uwarunkowaniach był Instytut Badań Społecznych. Można więc powiedzieć, że zainteresowanie psychologicznymi aspektami polityki pojawiło się niemal w tym samym okresie w USA oraz w Niemczech, i choć powody owego zainteresowania były nieco inne, to zbieżne było wsparcie psychoanalitycznej koncepcji osobowości behawioryzmem (Lasswell) lub marksizmem (szkoła frankfurcka) (Sears, Huddy, Jervis, 2008, s. 3; McGuire, 1993, s. 11-14).

6 Na temat pola semantycznego pojęcia wrogości międzygrupowej zob. Ziółkowski, 2013, s. 54-59. 
dzeniach (aspekt afektywny) oraz dyskryminacji (aspekt behawioralny) (Nelson, 2003, s. 28); wrogość międzygrupowa pojawia się wówczas, gdy owa postawa ma charakter negatywny (Duckitt, 2008, s. 513). Wszystkie omówione w tym artykule koncepcję są teoriami wyjaśniającymi przyczyny wrogości międzygrupowej, z uwzględnieniem wymienionych aspektów.

\section{Teoria krytyczna wobec faszyzmu i dalsze losy badań nad autorytaryzmem}

Bez wątpienia największym i najgłośniejszym wkładem teorii krytycznej do badań psychologii polityki była idea osobowości autorytarnej zrodzona w latach 30. i 40. XX wieku jako próba odpowiedzi na pytanie o psychologiczne podstawy faszyzmu. Trzeba podkreślić, że w tym miejscu nie mam zamiaru przedstawiać szczegółowo historii owej koncepcji i wszystkich jej przejawów - były one już wielokrotnie, kompetentnie i szczegółowo omawiane (Korzeniowski, 2002, s. 60-65; Jakubowska, 2005, s. 39-40; Skarżyńska, 2005, s. 43-47; Koralewicz, 2008, s. 135-156; Radkiewicz, 2012, s. 23-44). Warto jednak wspomnieć, że często jej zapomnianym punktem wyjścia były badania Ericha Fromma z 1929 roku przeprowadzone w grupach robotników i służby domowej, wśród których Fromm odkrył trzy rodzaje charakterów: radykalny, kompromisowy oraz autorytarny. Jak zauważył niemiecki psycholog, ten ostatni typ posiadał silną potrzebę bezpieczeństwa i identyfikacji z władzą, a występował szczególnie często u osób popierających NSDAP (Baars, Scheepers, 1993). Zanim jednak Erich Fromm skonceptualizował autorytaryzm jako formę ucieczki od wolności (co stało się w roku 1941), Wilhelm Reich opublikował pracę Psychologia mas wobec faszyzmu, w której kreślił związki między stłumioną seksualnością i autorytaryzmem. W jego ujęciu faszyzm był „postawą emocjonalną autorytarnie stłumionego człowieka cywilizacji maszynowej" (Reich, 2009, s. 13) - postawą powszechną w społeczeństwach kapitalistycznych i patriarchalnych, w których walka $\mathrm{z}$ własną seksualnością rodzi potrzeby kompensacji zaspokajane $\mathrm{w}$ ideologii honoru narodu. Innymi słowy, autorytaryzm był dla Reicha formą posłuszeństwa wobec silnej władzy wspieranej w instytucjach tradycyjnej rodziny oraz religii, pozwalał również przeciwdziałać procesom emancypacji społeczno-ekonomicznej oraz laicyzacji (Reich, 2009, s. 13, 27-31, 49, 71, 113-146).

Można powiedzieć, że od początku refleksja nad osobowością autorytarną koncentrowała się na relacji między lękiem i agresją. Ludzie autorytarni mieli postrzegać świat jako zagrażający, co prowadziło ich do postaw zwalczających inność i obcość, w których upatrywali źródła zagrożenia. Po raz pierwszy kwestie te jasno wyartykułował Fromm, dla którego autorytaryzm był jednym $z$ trzech 
sposobów (obok destruktywności i mechanicznego konformizmu) radzenia sobie z przerażeniem i bezsilnością ogarniającymi człowieka nowoczesnego, któremu nadmiar wolności nie tylko nie służy, lecz przeciwnie - napawa go lękiem i niemocą (Fromm, 2008, s. 40-108). Jeśli więc dialektyczny rozwój świata społecznego prowadzi nas do punktu, w którym wolność rodzi przerażanie, a autonomia - osamotnienie, to człowiek współczesny staje przed wielkim wyborem: pielęgnowania lub wyrzeczenia się siebie (Stenner, 2005, s. 143)7.

Wyrzekanie się siebie i swego rodzaju pozbywanie się „ja” wskutek lęku i ucieczki przed wolnością dokonuje się w dwojaki sposób: z jednej strony może to być stopienie się z ,innym” poprzez całkowite posłuszeństwo, krańcową uległość, jednostka stapia się z „my” poprzez zupełne podporządkowanie siebie i swojego życia ideom oraz idolom; z drugiej strony wyzbycie się „ja" może zostać osiągnięte na nieco paradoksalnej drodze pełnego panowania nad innym, jego zawłaszczenia, uprzedmiotowienia, „posiadania”, gdzie znów bezpieczne „ja” osiągane jest w jakimś „my”. Ten symbiotyczny stan, w którym „ja” zastępowane jest przez „my” (w XX wieku to najczęściej „my” wspólnoty narodowej lub rasowej), można więc osiągnąć poprzez masochizm lub sadyzm, niepojmowanych jednak w kategoriach zaburzeń seksualnych, lecz widzianych jako powszechne postawy społeczne (Fromm, 2008, s. 145-160). Krótko: osobowość autorytarna zawiera się w owej dialektyce charakteru sadomasochistycznego. Jak powiada niemiecki psycholog:

[...] charakterystycznym rysem sadomasochistycznego osobnika jest jego postawa wobec autorytetu. Podziwia go i skłonny byłby mu ulec, ale jednocześnie sam chciałby być autorytetem i podporządkować sobie innych (Fromm, 2008, s. 161).

Fromm, podobnie jak Reich, dostrzegał powszechność autorytaryzmu w nazistowskich Niemczech zwłaszcza wśród popierających Hitlera. Co za tym idzie, zarówno Fromm, jak i Reich byli rzecznikami przekonania, które w języku dzisiejszej psychologii polityki można by było nazwać asymetrią ideologiczną, a więc podkreśleniem istotnych, a nawet istotowych, różnic poznawczych i motywacyjnych między zwolennikami prawicy i lewicy. Nie wchodząc na razie w szczegóły, trzeba jeszcze dla porządku dodać, że w podobną stronę, choć opuszczając pole doświadczeń niemieckich, szedł Adorno.

Podobnie jak w przypadku koncepcji Fromma, dzieło Adorna i jego współpracowników (Else Frenkel-Brunswik, Daniel J. Levinson oraz R. Nevitt San-

Warto dodać, że w późniejszych pracach konflikt ten zostanie uogólniony w postaci rywalizacji biofilii i nekrofilii, a w konsekwencji dwóch wielkich modusów - bycia i posiadania (Fromm, 1999, s. 366-401; Fromm, 2000, s. 133-135, 147-148). 
ford) w zakresie osobowości autorytarnej jest doskonale znane i wszechstronnie opisane. Dość więc w tym miejscu przypomnieć, że ich punkt wyjścia był podobny, to jest poszukiwanie modelu osoby uprzedzonej, pozwalającej zrozumieć psychologiczne podstawy nazizmu, ale ich oparcie w teorii marksistowskiej było nieco mniejsze. Oto bowiem, o ile dla Fromma przeciwieństwem osobowości autorytarnej była osobowość rewolucyjna, o tyle dla Adorna i współpracowników była to osobowość demokratyczna. Innymi słowy, w miejsce dialektyki wolności lub niewoli badacze z Berkeley wprowadzili psychologiczne mechanizmy uprzedzeń lub ich braku (Jay, 1996, s. 131, 227). Również model osobowości autorytarnej, jako osobowości uprzedzonej, uległ znaczącym przekształceniom. Zdaniem Adorna cechuje go: konwencjonalizm, autorytarne podporządkowanie, autorytarna agresja, antyintracepcja, przesąd i stereotyp, kult siły i twardy charakter, destrukcyjność i cynizm, skłonność do projekcji oraz seksualność

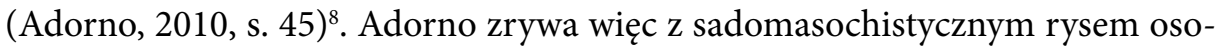
bowości autorytarnej, choć docenia jego wielką rolę w kształtowaniu się syndro$\mathrm{mu}$, co widać wyraźnie $\mathrm{w}$ jego rozważaniach nad rolą rodziny w tym procesie (Adorno, 2010, s. 318-322).

Omówione do tej pory - pokrótce i bardzo wybiórczo - poglądy Reicha, Fromma i Adorna na osobowość autorytarną są mocno zakorzenione, o czym była już mowa, w myśleniu krytycznym. U wszystkich tych autorów wyraźnie pobrzmiewa przekonanie, że świat pierwszej połowy XX wieku to okres wielkich konfliktów społecznych, politycznych, ekonomicznych oraz ideologicznych, u których podłoża leżą różnice psychologiczne. Przy czym dla Reicha są one raczej rezultatem siły patriarchalizmu i kapitalizmu epoki modernizacji, dla Fromma są one głównie szerokim polem rywalizacji o lepszą przyszłość - o zwycięstwo biofilii nad nekrofilią, Adorno zaś podkreśla mocno ich antydemokratyczny charakter. Bez względu jednak na odmienności owych spojrzeń kilka kwestii łączy trzech niemieckich psychologów: po pierwsze, są oni przekonani o konieczności odsłaniania i ujawniania zniewalającej siły autorytaryzmu dla jednostek i społeczeństw; po drugie, wiążą osobowość autorytarną z ideologiami prawicowymi; po trzecie, zgadzają się, że społeczeństwa bez autorytaryzmu byłyby dojrzalsze i moralnie lepiej rozwinięte. W tym sensie można nawet zaryzykować twierdzenie, że teoria krytyczna poszukująca zrozumienia dla ułomności posłusznych i na swój sposób bezrefleksyjnych autorytaryków wpisywała się

Innymi słowy, autorytarycy są przywiązani do konwencjonalnych wartości, ulegli wobec autorytetów grupy własnej i wrodzy wobec tych, których postrzegają jako łamiących zwyczajowe i powszechnie przyjęte zasady, są niewrażliwi i nieczuli, myślą sztywnymi kategoriami, widzą świat w kategoriach siły, przejawiają ogólną wrogość i pogardę wobec ludzi, są przekonani o tym, że na świecie dzieją się rzeczy niezwykłe, oraz są istotnie zainteresowani czynnościami seksualnymi, zwłaszcza innych osób, które pragną poddać kontroli. 
$\mathrm{w}$ wielowiekową tradycję teorii polityki poszukiwania warunków, jakie powinny być spełniane nie tylko przez „dobrego władcę”, ale także przez „dobrego obywatela" (Alford, 1993, s. 200).

Właściwy Reichowi, Frommowi i Adornowi problem ideologicznego uwikłania autorytaryzmu w postaci formułowania pytań o psychologiczne pochodzenie nazizmu lub osób uprzedzonych, a co za tym idzie - pytań o podstawy prawicowego radykalizmu, został zakwestionowany już w latach 50 . XX wieku, kiedy to pojawiły się głosy, że nie ma wielkiej różnicy między radykalizmami prawicowym oraz lewicowym i że są one przejawami tych samych mechanizmów, sam zaś autorytaryzm jest niewrażliwy politycznie i cechuje obie strony politycznego sporu. Jako pierwszy pogląd taki wyraził Edward Shils (zob. Roiser, Willig, 2002, s. 80-81), bardziej jednak znane są argumenty Hansa J. Eysencka (1999) i Miltona Rokeacha (1960). Podobnie jak wcześniej, nie ma potrzeby szeroko ich tu przedstawiać. Trzeba jednak zaznaczyć, że przekonania tych badaczy - bez względu na różnice między nimi występujące - stanowiły punkt przełomowy w historii refleksji nad autorytaryzmem, jako przyczyna wrogości międzygrupowej zrywały bowiem $\mathrm{z}$ jego ujmowaniem $\mathrm{w}$ kategoriach osobowości, otwierając drogę do koncepcji poznawczych oraz społecznych (Radkiewicz, 2011, s. 210). Mam przez to na myśli dwie ścieżki rozwoju badań nad autorytaryzmem: z jednej strony, nacisk kładziony na procesy poznawcze i sposób widzenia świata, a także zestaw przekonań właściwy osobom autorytarnym ${ }^{10}, \mathrm{z}$ drugiej strony,

9 Dość powiedzieć, że według Eysencka autorytarycy Fromm czy Adorno to w istocie osoby o twardej umysłowości, które posiadają najczęściej skrajne orientacje polityczne, nie lubią współpracować z innymi, są zamknięte, dominujące i agresywne. Co ważne, twardogłowi nie mają upodobania w jednym tylko typie ideologii - znaleźć ich można wśród faszystów, ale i komunistów (Eysenck, 1999, s. 132; Jakubowska, 2005, s. 45; Radkiewicz, 2012, s. 32-33). Rokeach tymczasem od lat 40. XX wieku badał problemy sztywności poznawczej autorytaryków. Jego wieloletnie zainteresowania doprowadziły go do idei dogmatyzmu, który definiował jako umysł zamknięty, nietolerujący poglądów innych niż własne oraz akceptujący poglądy podobne. Dogmatyzm, podobnie jak twardogłowość, jest politycznie niezależny od ideologii i można go odnaleźć zarówno pośród sympatyków prawicy, jak i lewicy. Trzeba podkreślić, że dogmatyków cechuje dominacja potrzeby bezpieczeństwa nad potrzebą adekwatnego poznania, a skoro tak, to są oni bezkrytyczni wobec poglądów własnych, wiele wiedzą o grupie własnej, ale niewiele o obcej, wyolbrzymiają podobieństwa i różnice między poglądami akceptowanymi i nieakceptowanymi, nie przyjmują także do wiadomości i często lekceważą informacje mogące podkopać ich przekonania (Rokeach, 1960, s. 4-5; Koralewicz, 2008, s. 149-150; Radkiewicz, 2012, s. 35-36).

10 Koncepcja autorytaryzmu jako zestawu poglądów i przekonań, które utrzymuje jednostka i poprzez które postrzega ona świat społeczny, została bodaj najpełniej wyrażona przez Boba Altemeyera. Kanadyjski psycholog zredefiniował kategorie Adorna i użył trzech z nich (choć w innym sensie, o czym trzeba pamiętać), by opisać autorytaryzm prawicowy (right-wing authoritarianism - RWA) jako kowariancję autorytarnej uległości, autorytarnej agresji oraz konwencjonalizmu (Altemeyer, 1996, s. 6). 
zależność owych postaw od czynników społecznych, od okoliczności (w szczególności zagrożenia), które uruchamiają i wzmacniają myślenie autorytarne ${ }^{11}$. Gwoli ścisłości można dodać, że wraz z tymi przekształceniami teorii autorytaryzmu zupełnemu zanegowaniu uległy elementy teorii krytycznej. Pojawiły się one znów w latach 90. XX wieku, jako część teorii uzasadniania systemu (System Justification Theory - dalej: SJT).

\section{Fałszywa świadomość w teorii uzasadniania systemu}

Warto rozpocząć od uwagi, że o ile refleksja nad autorytaryzmem zaliczana jest do „dyspozycyjnych wyjaśnien” uprzedzeń i wrogości, a więc takich, które odnoszą się do cech jednostki, o tyle SJT jest koncepcją wyjaśniającą wrogość na gruncie „sytuacyjnym”, co oznacza, że widzi ona jej przyczyny w czynnikach zewnętrznych, zwłaszcza w charakterze relacji między grupami i okolicznościach owej relacji (Duckitt, 2008, s. 526).

SJT wyrasta $\mathrm{z}$ problemu zauważonego jeszcze przez twórców bodaj najbardziej płodnej teorii wyjaśniającej relacje międzygrupowe, to jest teorii tożsamości społecznej. Warto przypomnieć, że punktem wyjścia rozważań Henriego Tajfela oraz Johna C. Turnera było pytanie, dlaczego rywalizacja społeczna nie zawsze prowadzi do otwartego konfliktu i w przypadku niemożności zaspokojenia potrzeb stron sporu nie zawsze pojawia się przemoc i walka. Innymi słowy, Tajfel i Turner wyszli poza sytuację opisaną przez Muzafera Sherifa w teorii rzeczywistego konfliktu grupowego i uznali, że członkowie grup społecznie podporządkowanych lub w jakimś stopniu dyskryminowanych nie zawsze będą dążyli do konfrontacji z grupą dominującą, lecz podejmą inne działania mające na celu poprawę ich pozycji. Mogą to być zmiana wymiaru porównań międzygrupowych (np. „honorowa przegrana” zmienia wymiar porównań z rywalizacji sportowej na „styl” owej rywalizacji), redefinicja wartości porównań międzygrupowych (np. po przegranych zawodach sportowych umniejsza się pierwotną wartość celu), porównanie $\mathrm{z}$ nową grupą (np. gdy wstyd $\mathrm{z}$ powodu przegranej w piłkę nożną

11 Przekonanie o silnym wpływie okoliczności i czynników sytuacyjnych na aktywację i ujawnienie się postaw autorytarnych zostało najpierw opisane przez Johna Duckitta, a następnie rozwinięte przez Josta Stellmachera i Thomasa Petzela. Nie wchodząc w szczegóły obu koncepcji, trzeba podkreślić, że zbliżają one rozważania nad autorytaryzmem do teorii tożsamości społecznej i ujmują go jako wyobrażenie na temat pożądanych relacji między jednostką i społeczeństwem, nie negując trzech składowych autorytaryzmu wskazanych przez Altemeyera, podkreślają jednak, że nie są one trwałymi i głęboko umiejscowionymi postawami, lecz są aktywowane pod wpływem zagrożenia, a ich siła zależy od stopnia identyfikacji grupowej (Duckitt, 1989, s. 63-82; Stellmacher, Petzel, 2005, s. 245-272). 
przykrywany jest przez dumę ze zwycięstwa w siatkówce), a także podjęcie działań w celu poprawy sytuacji grupy (np. program szkolenia młodych mistrzów sportu). Te sposoby - określone przez twórców teorii tożsamości społecznej mianem „rywalizacji społecznej” w ramach „społecznej zmiany” - mają charakter grupowy. Obok nich jednostka może jeszcze podjąć próbę „mobilności indywidualnej" i poprzez pracę własną zmienić pozycję społeczną (Tajfel, Turner, 1979, s. 43-46; Tajfel, Turner, 1986, s. 19-20; Hogg, Abrams, 1988, s. 48-52).

W największym skrócie można powiedzieć, że teoria tożsamości społecznej zakłada, że ludzie motywowani są do posiadania wysokiej samooceny, zaspokajanej w ramach porównań międzygrupowych i są skłonni do porzucania tych identyfikacji, które nie dają im pozytywnej samooceny. Jednocześnie bodaj najistotniejszą konsekwencją porównań międzygrupowych jest zjawisko faworyzacji grupy własnej i dyskryminacji grupy obcej, które pojawia się automatycznie, gdy jednostka umieści siebie w kontekście jakiegoś „my”, szukając w tożsamości grupowej pozytywnej samooceny (Tajfel, Turner, 1979, s. 40; Tajfel, Turner, 1986, s. 16). Innymi słowy, zawsze gdy myślimy o sobie jako o członkach pewnej grupy, to owa grupa wydaje nam się lepsza. Rzecz jasna zjawiska faworyzacji grupy własnej i dyskryminacji grupy obcej mogą narastać i prowadzić do radykalizacji zachowań, jawnej dyskryminacji i odczłowieczania grupy obcej.

Świat społeczny opisywany przez teorię tożsamości społecznej jest więc pełny rywalizacji, której celem jest pozycja grupy własnej, dająca pozytywną samoocenę. W takim świecie na porządku dziennym powinniśmy obserwować mniejsze lub większe rewolty i bunty wyrażające dążenie do zmiany pozycji grup podporządkowanych. Tak się jednak nie dzieje i powszechniejsze zdają się działania mające na celu zachowanie krzywdzących struktur społecznych, także przez tych, którzy są obiektem owej krzywdy. Jak bowiem można inaczej interpretować trwanie systemów społecznej dominacji w postaci niewolnictwa, społeczeństw kastowych, skrajnych nierówności ekonomicznych i innych jeszcze? Nie mogłyby one funkcjonować bez wsparcia tych, którzy są ich ofiarami. Leżące $\mathrm{u}$ ich podłoża zjawiska faworyzacji grupy obcej oraz dyskryminacji grupy własnej istnieją więc i są całkiem częste (Wojciszke, 2010, s. 279). Były one co prawda przewidywane przez teorię tożsamości społecznej, lecz nie zostały szerzej opisane. Dokonali tego dopiero John T. Jost oraz Mahzarin R. Banaji w ramach teorii uzasadniania systemu (Jost, Banaji, 1994, s. 7-8).

Warto rozpocząć od uwagi, że systemem w ramach SJT jest dowolna forma zorganizowania społecznego bez względu na wielkość, funkcje czy reguły formalne, na przykład państwo, rodzina, organizacje pozarządowe, kościoły, kluby sportowe, grupy przyjaciół, zespoły rockowe (van der Toorn, Jost, 2014, s. 413-414). „Uzasadnianie” systemów społecznych, a więc postrzeganie ich jako prawomocnych nawet wówczas, gdy są opresyjne, jest odpowiedzią na silną po- 
trzebę życia w świecie przewidywalnym, niezmiennym, stabilnym (Jost, Banaji, 1994, s. 2-3; Jost, 2015, s. 622). Motywacja do uzasadniania systemu jest wszakże zmienna i zależna od czynników dyspozycyjnych, a więc zarówno od cech indywidualnych (przede wszystkim epistemicznych, egzystencjalnych i relacyjnych), jak i od czynników sytuacyjnych, zwłaszcza postrzeganego zagrożenia (van der Toorn, Jost, 2014, s. 414).

Jost i Banaji sformułowali w ramach SJT cały szereg hipotez, które w toku wieloletnich badań empirycznych zyskały sporą liczbę potwierdzeń. Nie ma potrzeby szczegółowo ich tu relacjonować, warto jednak wspomnieć, że SJT przewiduje między innymi, że: (1) głównymi narzędziami racjonalizacji i legitymizacji status quo są stereotypy, które będą się nasilać w sytuacjach zagrożenia, będą też postrzegane jako bardziej uzasadnione i „prawdziwe”; (2) faworyzacja grupowa jest zjawiskiem powszechnym i, co ważne, na poziomie postaw utajonych wśród członków grup o niskim statusie obserwować można faworyzację grupy obcej, podczas gdy członkowie grup o wysokim statusie będą faworyzowali grupę własną, zgodnie z przewidywaniami teorii tożsamości społecznej; (3) wzrost spostrzeganej legitymizacji systemu prowadzić będzie do wzrostu faworyzacji grupowej zgodnie $\mathrm{z}$ kierunkiem opisanym w punkcie drugim; (4) faworyzacja grupy obcej przez członków grup podporządkowanych znajdzie wyraz, między innymi, w przypisywaniu sobie mniej uprawnień przez członków takich grup, będą oni także gorzej siebie oceniali; (5) uzasadnienie systemu jest często wyższe w grupach podporządkowanych, a także w społeczeństwach o dużych nierównościach ekonomicznych (por. Jost, Banaji, Nosek, 2004, s. 899-911).

Uzasadnienie systemu dokonuje się za sprawą stereotypów. Co ważne, w ramach SJT bada się przede wszystkim dwa rodzaje stereotypów: komplementarne i niekomplementarne. Te pierwsze mają na celu zrównoważenie negatywnych cech przypisanych osobom z grupy podporządkowanej, te drugie nie odgrywają takiej roli, podkreślając i wzmacniając cechy negatywne, obwiniając "gorszych" za ich los. Przykładami stereotypów komplementarnych są „biedny, ale szczęśliwy”, lub „przegrany, ale honorowy”, przykładami stereotypów niekomplementarnych są zaś „biedny i nieszczęśliwy” lub „przegrany i niehonorowy” (Blasi, Jost, 2006, s. 1134-1135). Innymi słowy, te pierwsze stereotypy mają na celu uzasadnienie systemu w nieco przewrotny sposób, poniekąd bowiem wynagradzają podporządkowanym ich niski status, choć w wymiarze mniej istotnym niż powód ich upośledzenia. Te drugie dyskryminują podwójnie: uzasadniają system, podkreślając, że nie ma w nim błędów, zgodnie przekonaniem, że gdy ktoś jest krzywdzony, to widać sam na to zasłużył. Skrajnym przykładem stereotypów niekomplementarnych są więc słyszalne niekiedy głosy, że ofiary gwałtów są same sobie winne i nie powinny prowokować albo że oszukani i okradzeni przez nieuczciwych pożyczkodawców widzieli, co podpisywali, i nie ma się 
co nad nimi litować, o pomocy nie wspominając. Co ciekawe, stosowanie stereotypów komplementarnych lub niekomplementarnych zależy w istotny sposób od orientacji politycznej. Okazuje się bowiem, że osoby o przekonaniach prawicowych częściej są skłonne do stosowania stereotypów niekomplementarnych, a osoby o poglądach lewicowych - do stereotypów komplementarnych (Kay, Czapliński, Jost, 2009, s. 291, 296).

Mając tak zarysowane podstawowe twierdzenia SJT, można się skupić na elementach krytycznej teorii w niej zawartych. Jost i Banaji postanowili bowiem wykorzystać ideę fałszywej świadomości do opisania procesów uzasadniania systemu za sprawą stereotypów. W swoim programowym artykule zauważają:

Stereotypy, które są rozpowszechnionymi przekonaniami na temat grup społecznych towarzyszą przypuszczalnie wszystkim systemom cechującym się podziałem na role, klasy, pozycje i statusy, albowiem takie układy bywają wyjaśniane i postrzegane, jako uzasadnione przez tych, którzy w nich uczestniczą.

Centralna dla tej dyskusji jest idea fałszywej świadomości definiowanej $\mathrm{w}$ tym miejscu jako podtrzymywanie przekonań sprzecznych z osobistym lub grupowym interesem jednostki i która tym samym przyczynia się do utrzymania niekorzystnej pozycji jednostki lub grupy (Jost, Banaji, 1994, s. 3).

Innymi słowy, idea fałszywej świadomości (pojmowanej w mocno ograniczony i powierzchowny sposób, co uzasadnić można chyba tylko względną łatwością operacjonalizacji pojęcia do badań empirycznych) pozwala poszerzyć listę motywów skłaniających do społecznej rywalizacji i konfliktów. Na gruncie teorii tożsamości społecznej można bowiem wyróżnić dwa takie zasadnicze motywy (choć Tajfel i Turner, o czym warto pamiętać, w taki sposób o tym nie pisali), to jest walkę o poprawę pozycji indywidualnej oraz walkę o poprawę pozycji grupowej. SJT przejmuje te dwa elementy, dodając trzeci, oparty właśnie na idei fałszywej świadomości. W ramach teorii uzasadniania systemu twierdzi się mianowicie, że w przypadku, gdy stereotypy służą ochronie pozycji własnej jednostki i jej interesów, mowa o uzasadnieniu osobistym (ego justification), gdy stereotypy służą ochronie pozycji grupy i jej interesów, w grę wchodzi uzasadnienie grupowe (group justification), gdy zaś motywy osobiste i grupowe łączą się w celu ochrony porządku społecznego, jego stabilności i trwałości, nawet jeśli oznacza to działanie przeciw interesom indywidualnym lub grupowym, to mamy wówczas do czynienia z uzasadnieniem systemu (Jost, Banji, 1994, s. 3-11; Jost, Banaji, Nosek, 2004, s. 887-889). Ten ostatni poziom funkcjonuje głównie jako fałszywa świadomość, ponieważ tylko w takim przypadku można zrozumieć, dlaczego krzywdzeni nie chcą zmienić swojego położenia (Jost, Banaji, 1994, s. 10).

Jost i Banaji postrzegają fałszywą świadomość jako ważny element uzasadniania systemu i to bez względu na to, czy jest on sprawiedliwy, czy nie - system 
jest uzasadniany wyłącznie $z$ tego tylko powodu, że istnieje, a skoro tak, to daje poczucie stabilności i bezpieczeństwa. Mechanizm powstawania i utrzymywania stereotypów, obejmujący klasyfikowanie pewnych bodźców świadczących o niskiej pozycji społecznej lub jakiejś formie społecznego upośledzenia, ma więc postać błędnego koła w tym sensie, że to, co aktywuje stereotypy, jest jednocześnie tym, co służy uzasadnieniu nierówności, tak jak to się dzieje w przypadku stereotypu robotników, gdzie postrzeganie ich:

[...] jako nieinteligentnych, niekompetentnych, brudnych i nierzetelnych może służyć ideologicznej funkcji racjonalizacji ich położenia ekonomicznego. Podobieństwa między stereotypami klasy niższej oraz Afroamerykanów doprowadziły niektórych do przekonania, że stereotypy rasowe zostały wywiedzione z niekorzystnej sytuacji ekonomicznej, co jest zbieżne z naszym rozumowaniem (Jost, Banaji, 1994, s. 12).

Innymi słowy, być może różnice ekonomiczne są na tyle istotne, że umożliwiają zbieżną stereotypizację "gorszych" i to pomimo różnic rasowych, które powszechnie uznawane są za najistotniejsze czynniki dyferencjacji grupowej. Podobnie dzieje się w przypadku stereotypów płciowych. Jost i Banaji przypominają o badaniach, zgodnie z którymi postrzeganie kobiet jako bardziej współpracujących i społecznych może być wynikiem zajmowania przez nie określonej pozycji związanej z opieką nad domem. W innych badaniach okazało się również, że istnieje wielki wpływ męskich i kobiecych ról społecznych, a także zajmowanych przez mężczyzn i kobiety pozycji na zawartość stereotypów płciowych (Jost, Banaji, 1994, s. 12-13) ${ }^{12}$. Mimo wszystko SJT jest daleka od redukcjonizmu ekonomicznego. W tworzeniu stereotypów ważną rolę odgrywają nierówności płciowe, rasowe, etniczne, religijne, różnice orientacji seksualnej i inne, choć pierwszeństwo mają obiektywne sprzeczności interesów oraz związane z tym różnice ekonomiczne (Jost, Banaji, 1994, s. 17).

Jak zauważają Jost i Banaji, prawdopodobnymi czynnikami uaktywniającymi uzasadnienie systemu (zamiast dwóch pozostałych uzasadnień - ego i grupowego) mogą być brak świadomości klasowej, separacja i odizolowanie członków

12 Można dodać, że w analizowaniu stereotypów jako narzędzia utrzymującego nierówności społeczne SJT wspiera się na wielu innych koncepcjach. Jedną z nich jest teoria sprawiedliwego świata (Just-World Theory) sformułowana przez Melvina Lernera, według której świat sprawiedliwy to taki, który jest przewidywalny. Zgodnie z wynikami badań ludzie są skłonni do negatywnej samooceny, jeśli służyć to będzie ochronie sprawiedliwego świata - są wówczas skłonni do obwiniania siebie. Inna jeszcze jest koncepcja „,poznawczego konserwatyzmu”, ukazująca, jak funkcjonuje selektywne przetwarzanie informacji i zapamiętywanie po to, by zachować pewną bezpieczną wizję świata. SJT czerpie także z idei postaw ukrytych, a więc takich, których aktywacja ma charakter automatyczny, a one same pojawiają się poza procesami świadomymi (Jost, Banaji, 1994, s. 12-16). 
grupy, niski stopień identyfikacji członków grup podporządkowanych, bodźce aktywujące automatyczne przetwarzania stereotypów oraz opresyjność systemu, w tym sensie, że im bardziej jest on krzywdzący, tym większe uzasadnienie systemu wywołuje (Jost, Banaji, 1994, s. 16).

Próbując dokonać oceny wykorzystania idei fałszywej świadomości przez SJT, trudno nie odnieść wrażenia, że została ona użyta powierzchownie i w oderwaniu od długiej historii koncepcji. W tym kontekście Martha Augoustinos zarzuca Jostowi i Banaji, że błędnie stosują pojęcie fałszywej świadomości, redukując ją do psychologicznego (a dokładniej poznawczego) wymiaru i ignorując to, co jest najistotniejsze, a więc związek fałszywej świadomości z historycznymi przekształceniami kapitalizmu (Augoustinos, 1999, s. 296, 302). Inaczej mówiąc, fałszywa świadomość jest dla nich raczej hasłem, nośną kategorią organizującą myślenie o nierównościach i samouzasadnieniach krzywd i opresji przez słabszych i "gorszych" - nie jest natomiast inherentną częścią teorii, o czym świadczy także fakt, że w późniejszych tekstach z zakresu SJT pojęcie fałszywej świadomości pojawia się bardzo rzadko. Oczywiście Jost i Banaji nie rezygnują w nich z mechanizmów opisanych w tekście z 1994 roku i nie zmieniają swojej koncepcji, ale nie stosują więcej określenia „fałszywa świadomość, nie wyjaśniając, co skłania ich do tej rezygnacji. Mamy więc sytuację zadziwiającą, a mianowicie owa fałszywa świadomość dalej jest obecna, nie znikają bowiem mechanizmy uzasadniania systemu i nie znika ich podstawowy wymiar: faworyzacja grupy obcej i dyskryminacja grupy własnej. Nie oznacza to jednak, że włączenie kategorii fałszywej świadomości do refleksji nad stereotypami jest jedynie nic nie znaczącym epizodem. Przeciwnie, wydaje się to bardzo ważnym zabiegiem uświadamiającym funkcje, jakie stereotypy pełnią w podtrzymywaniu nierówności społecznych i uzasadnieniu krzywd. Wprowadza również do mainstreamowej psychologii polityki wątki dawno nieobecne, to jest język teorii krytycznej, i nawet jeśli nie oznacza to szerokiego otwarcia bram dla refleksji krytycznej, to zostały one uchylone.

\section{Zamiast podsumowania. Czy jest miejsce dla teorii krytycznej w głównym nurcie badań psychologii polityki?}

Celem tego artykuły było zarysowanie elementów teorii krytycznej w psychologii polityki z uwzględnieniem zarówno jej bogatej historii (osobowość autorytarna), jak i współczesnych badań nad zjawiskiem wrogości międzygrupowej (teoria uzasadniania systemu). Intencjonalnie więc pominąłem tu intrygujące i płodne poznawczo pole psychologii krytycznej, skupiając się na obszarze, na którym elementy teorii krytycznej pojawiają się dziś rzadko, a nawet więcej - 
są, jak się zdaje, gościem niezwykłym i niecodziennym. Dzieje się tak oczywiście głównie ze względu na wymogi metodologiczne stawiane w głównym nurcie psychologii polityki, a związane zarówno z przekonaniem o konieczności abstrahowania od wartości w poznaniu naukowym, jak i z trudnościami z konceptualizacją i operacjonalizacją abstrakcyjnych i pojemnych semantycznie kategorii refleksji krytycznej. Niemniej jednak, jak starałem się wykazać, elementy teorii krytycznej do dziś pojawiają się w mainstreamie psychologii polityki, czego przykładem jest przekonanie Josta i Banaji, że stereotypy uzasadniające system funkcjonują jako fałszywa świadomość. Mam jednak silne przekonanie, że możliwości wykorzystania teorii krytycznej dla psychologii polityki są większe. Argumentów na rzecz takiego przekonania można podać wiele, ja ograniczę się do trzech.

Po pierwsze, jak wspominałem wcześniej, badania nad osobowością autorytarną wprowadziły do psychologii polityki przekonanie, że zwolennicy lewicy i prawicy mogą istotnie się różnić na poziomie poznawczo-motywacyjnym; zjawisko to Jost określa mianem asymetrii ideologicznej. Taka asymetria, jak widzieliśmy, została zakwestionowana wraz z krytyką osobowości autorytarnej Shilsa, Eysencka i Rokeacha, obecnie jednak wraca za sprawą wielu badań, które pokazują jej istnienie między innymi dla takich zmiennych, jak dogmatyzm, sztywność poznawcza, potrzeba struktury, potrzeba tolerancji wieloznaczności, potrzeby poznania i innych jeszcze (Jost, 2017, s. 168-196). Wartościowe mogłoby się okazać wykorzystanie refleksji krytycznej do zrozumienia historycznego, społecznego, ekonomicznego i politycznego kontekstu owych różnic, które uzupełniłoby wyjaśnienia poznawczo-motywacyjne.

Po drugie, jak przypomina Jonathan Haidt, współczesne badania psychologiczne prowadzone są głównie wśród dobrze wyedukowanych respondentów mieszkających w zamożnych, demokratycznych i wysoko uprzemysłowionych krajach Zachodu. Co za tym idzie, są to respondenci o tyle „dziwni” ( $\mathrm{z}$ ang. WEIRD - western, educated, industrialized, rich, democratic), że większość ludzi na świecie posiada inne „parametry” socjodemograficzne: to osoby raczej słabo wyedukowane, żyjące w krajach niezamożnych, często w kulturach agrarnych, nierzadko niedemokratycznych. Ma to swoje istotne przełożenie na badania dotyczące moralności, które przeprowadził Haidt, ponieważ „dziwni” postrzegają świat w kategoriach odrębnych obiektów (autonomicznych „ja”), pozostali zaś w kategoriach relacji, a więc socjocentrycznych „ja” (Haidt, 2014, s. 138-140). Idąc dalej, można uznać, że wyniki badań części przynajmniej eksperymentów (z pewnością nie wszystkich, być może nie większości) są więc obarczone błędem „europocentryzmu” i mogą nie być miarodajne dla osób żyjących poza WEIRD. Refleksja krytyczna, wraz z jej czułością na mechanizmy politycznej dominacji, zwłaszcza świata Zachodu, nad innymi obszarami i systemami mog- 
łaby wnieść wiele wątków korygujących i uzupełniających istniejące teorie. Ponadto refleksja krytyczna mogłaby również uwrażliwić badaczy na potencjalne problemy badań, w szczególności polityczne uwikłanie eksperymentów. Zarzuca się bowiem niekiedy eksperymentatorom, że ich badania nie tyle odwzorowują sytuacje społeczno-polityczne w warunkach kontrolowanych, ile tworzą nowe i czasem niespecyficzne relacje władzy i podporządkowania (Spears, Smith, 2001, s. 312-313).

Po trzecie, jeśli zgodzimy się z przekonaniem Douglasa Kellnera, że współczesna, przemyślana przez pryzmat postmoderny refleksja krytyczna to teoria, która pozbawiona jest relatywistycznego oraz nihilistycznego balastu i jako taka jest normatywną teorią zawierającą $\mathrm{w}$ sobie wielki ładunek emancypacji, to jest ona w sposób zupełnie oczywisty teorią ściśle polityczną w takim znaczeniu, że nie tylko politykę opisuje i wyjaśnia, ale ją współtworzy. Jej silny związek z rzeczywistością społeczną i skupianie się na odkrywaniu jej aspektów, wymiarów, płaszczyzn i tego, co ukryte, sprawia, że jest ona czymś więcej niż tylko zabawą retoryczną, subtelną grą znaczeń i sensów - ona ich nie tworzy, lecz je odsłania, czyniąc świat widzialnym (Kellner, 1990, s. 12, 31). Teoria krytyczna więc, jako teoria supradyscyplinarna, nie tyle łączy (inter-)rozproszone wątki różnych dyscyplin, ile tworzy nową teorią społeczną, przekraczającą i integrującą dotychczasowe dokonania. Zgadzając się z tymi uwagami, można argumentować na rzecz konieczności szerszego włączenia refleksji krytycznej do badań psychologii polityki, tyle tylko, że nie jest to nic nowego, bo takie właśnie są postulaty psychologów krytycznych.

Wszystko to moim zdaniem prowadzi do wniosku, że nawet jeśli teoria krytyczna nie jest dominującą perspektywą badań w głównym nurcie psychologii polityki, to jest miejsce dla niej w tym obszarze, ona sama zaś może wnieść tu wiele intersujących i wartościowych kategorii i zagadnień.

\section{Literatura}

Adorno, Th.W. (2010). Osobowość autorytarna. Warszawa: Wydawnictwo Naukowe PWN.

Alford, C.F. (1993). „Introduction to the Special Issue on Political Psychology and Political Theory". Political Psychology, 14 (2), s. 199-208.

Altemeyer, P. (1996). The Authoritarian Specter. London: Harvard University Press.

Augoustinos, M. (1999). „Ideology, False Consciousness, and Psychology”. Theory \& Psychology, 9 (3), s. 295-312.

Baars, J., Scheepers, P. (1993). „Theoretical and methodological foundations of the authoritarian personality". Journal of the History of the Behavioral Science, 29, s. 345-353. 
Blasi, G., Jost, J.T. (2006). „System Justification Theory and Research: Implications for Law, Legal Advocacy, and Social Justice”. California Law Review, 94 (4), s. $1119-1168$.

Duckitt, J. (1989). „Authoritarianism and Group Identification: A New View of an Old Construct”. Political Psychology, 10 (1), s. 63-84.

Duckitt, J. (2008). „Uprzedzenia i wrogość między grupami”. W: D.O. Sears, L. Huddy, R. Jervis (red.). Psychologia polityczna, przeł. R. Andruszko. Kraków: Wydawnictwo Uniwersytetu Jagiellońskiego.

Eysenck, H.J. (1999). The Psychology of Politics. New Brunswick-London: Transaction Publishers.

Fox, D., Prilleltensky, I., Austin, S. (eds.) (2009). Critical Psychology: An Introduction. London: Sage Publications Ltd.

Fromm, E. (1999). Anatomia ludzkiej destrukcyjności, przeł. J. Karłowski. Poznań: Dom Wydawniczy Rebis.

Fromm, E. (2000). Mieć czy być?, przeł. J. Karłowski. Poznań: Rebis.

Fromm, E. (2008). Ucieczka od wolności, przeł. O. i A. Ziemilscy. Warszawa: Spółdzielnia Wydawnicza „Czytelnik”.

Gergen, K.J. (1973). „Social Psychology as History”. Journal of Personality and Social Psychology, 26 (2), s. 309-320.

Gergen, K.J. (2009). Nasycone Ja. Dylematy tożsamości w życiu współczesnym, przeł. M. Marody. Warszawa: Wydawnictwo Naukowe PWN.

Haidt, J. (2014). Prawy umyst. Dlaczego dobrych ludzi dzieli religia i polityka?, przeł. A. Nowak-Młynikowska. Sopot: Smak Słowa.

Hogg, M.A., Abrams, D. (1998). Social Identifications: A Social Psychology of Intergroup Relations and Group Processes. London: Routledge.

Hook, D. (2004). „Critical Psychology: The Basic Co-ordinates”. W: D. Hook, N. Mkhize, P. Kiguwa, A. Collins, E. Burman, I. Parker (eds.). Critical Psychology. Lansdowne: Juta and Company Ltd.

Jakubowska, U. (2005). Ekstremizm polityczny. Studium psychologiczne. Gdańsk: Gdańskie Wydawnictwo Psychologiczne.

Jay, M. (1996). The Dialectical Imagination: A History of the Frankfurt School and the Institute of Social Research 1923-1950. Berkeley-Los Angeles-London: University of California Press.

Jost, J.T. (2015). „Resistance to Change: A Social Psychological Perspective”. Social Research, 82 (3), s. 607-636.

Jost, J.T. (2017). „Ideological Asymmetries and the Essence of Political Psychology”. Political Psychology, 38 (2), s. 167-208.

Jost, J.T., Banaji, M.R. (1994). „The Role of Stereotyping in System-justification and the Production of False Consciousness". British Journal of Social Psychology, 33, s. $1-27$. 
Jost, J.T., Banaji, M.R., Nosek, B.A. (2004). „A Decade of System Justification Theory: Accumulated Evidence of Conscious and Unconscious Bolstering of the Status Quo". Political Psychology, 25 (6), s. 881-919.

Kay, A.C., Czapliński, Sz., Jost, J.T. (2009). „Left-right Ideological Differences in System Justification Following Exposer to Complementary versus Noncomplementary Exemplars". European Journal of Social Psychology, 39, s. 290-298.

Kellner, D. (1990). „Critical Theory and Crisis of Social Theory”. Social Perspectives, 33 (1), s. 11-33.

Koralewicz, J. (2008). Autorytaryzm, lęk, konformizm. Warszawa: Wydawnictwo Naukowe Scholar / Collegium Civitas Press.

Korzeniowski, J. (2002). „Autorytaryzm i jego psychopolityczne konsekwencje”. W: K. Skarżyńska (red.). Podstawy psychologii polityki. Poznań: Zysk i S-ka.

McGuire, W.J. (1993). „The Poly-Psy Relationship: Three Phases of a Long Affair”. W: S. Iyengar, W.J. McGuire (eds.). Explorations in Political Psychology. DurhamLondon: Duke University Press.

Monroe, K.R., Chiu, W., Martin, A., Portman, B. (2009). „What Is Political Psychology?”. Political Psychology, 7 (4), s. 859-882.

Nelson, T.D. (2003). Psychologia uprzedzeń. Gdańsk 2003: Gdańskie Wydawnictwo Psychologiczne.

Parker, I. (1999). „Critical Psychology: Critical Links”. Annual Review of Critical Psycho$\log y, 1$, s. 3-18.

Parker, I. (2015). „Introduction. Principles and Positions”. W: I. Parker (ed.). Handbook of Critical Psychology. London-New York: Routledge.

Radkiewicz, P. (2011). „Autorytaryzm jako ideologiczna wizja świata społecznego i jako postawa wobec własnej grupy. Co jest bliższe istoty zjawiska?”. W: M. Kofta, M. Bilewicz (red.). Wobec obcych. Zagrożenia psychologiczne a stosunki międzygrupowe. Warszawa: Wydawnictwo Naukowe PWN.

Radkiewicz, P. (2012). Autorytaryzm a brzytwa Ockhama. Warszawa: Wydawnictwo Naukowe Scholar.

Reich, W. (2009). Psychologia mas wobec faszyzmu, przeł. E. Drzazgowska, M. Abraham-Diefenbach. Warszawa: Wydawnictwo Aletheia.

Roiser, M., Willig, C. (2002). „The Strange Death of the Authoritarian Personality: 50 Years of Psychological and Political Debate". History of the Human Science, 15 (4), s. 71-96.

Rokeach, M. (1960). The Open and Closed Mind: Investigations into the Nature of Belief Systems and Personality Systems. New York: Basic Books.

Sears, D.O., Huddy, L., Jervis, R. (2008). „Psychologie leżące u podstaw psychologii politycznej". W: D.O. Sears, L. Huddy, R. Jervis (red.). Psychologia polityczna, przeł. R. Andruszko. Kraków: Wydawnictwo Uniwersytetu Jagiellońskiego.

Skarżyńska, K. (2005). Człowiek a polityka. Zarys psychologii politycznej. Warszawa: Wydawnictwo Naukowe Scholar. 
Spears, R., Smith, H.J. (2001). „Experiments as Politics”. Political Psychology, 22 (2), s. 309-330.

Stellmacher, J., Petzel, T. (2005). „Authoritarianism as a Group Phenomenon”. Political Psychology, 26 (2), s. 245-274.

Stenner, K. (2005). The Authoritarian Dynamic. Cambridge: Cambridge University Press. Tajfel, H., Turner, J.C. (1979). „An Integrative Theory of Intergroup Conflict”. W: W.G. Austin, S. Worchel (eds.). The Social Psychology of Intergroup Relations. Monterey, CA: Brooks-Cole Publishing Company.

Tajfel, H., Turner, J.C. (1986). „The Social Identity Theory of Intergroup Behavior”. W: S. Worchel, L.W. Austin (eds.). Psychology of Intergroup Relations. Chicago: Nelson-Hall.

Teo, Th. (1999). „Methodologies of Critical Psychology: Illustrations from the Field of Racism”. Annual Review of Critical Psychology, 1, s. 119-134.

Teo, Th. (2012). „Critical Psychology”. W: R.W. Rieber (ed.). Encyclopedia of the History of Psychological Theories. New York: Springer.

Toorn, J. van der, Jost, J. (2014). „Twenty Years of System Justification Theory: Introduction to the Special Issue on Ideology and System Justification Processes". Group Processes \& Intergroup Relations, 17 (4), s. 413-419.

Wojciszke, B. (2010). Sprawczość i wspólnotowość. Podstawowe wymiary spostrzegania społecznego. Gdańsk: Gdańskie Wydawnictwo Psychologiczne.

Ziółkowski, J. (2013). Wrogość w stosunkach politycznych. Modelowa analiza funkcjonalna. Warszawa: Dom Wydawniczy Elipsa.

\section{Streszczenie}

W artykule zaprezentowano wybrane aspekty refleksji krytycznej w obszarze mainstreamu psychologii polityki, ze szczególnym uwzględnieniem wrogości międzygrupowej. Punktem wyjścia jest krótkie omówienie obszaru badań i specyfiki metodologicznej współczesnej psychologii krytycznej, po czym przedstawione są główne wpływy refleksji krytycznej na psychologię polityki głównego nurtu, to jest osobowość autorytarna oraz idea stereotypów jako fałszywej świadomości w teorii uzasadniania systemu. Artykuł kończą krótkie rozważania nad przydatnością refleksji krytycznej w obszarze badań mainstreamowej psychologii polityki.

Słowa kluczowe: teoria krytyczna, osobowość autorytarna, teoria uzasadnienia systemu, teoria polityki, psychologia polityki 